\title{
Fischer mono and biscarbene complexes of tungsten with mono and dimeric heteroaromatic substituents
}

Marilé Landman, ${ }^{\mathrm{a}, *}$ Blenerhassitt E. Buitendach, ${ }^{\mathrm{b}}$ Marrigje M. Conradie, ${ }^{\mathrm{b}, \mathrm{c}}$ Roan Fraser, ${ }^{\mathrm{a}}$ Petrus H. van Rooyen $^{\mathrm{a}}$ and Jeanet Conradie, ${ }^{\mathrm{b}, \mathrm{c} *}$

${ }^{a}$ Chemistry Department, University of Pretoria, Private Bag X20, Hatfield, 0028, South Africa. Tel: 27-12-4202527 Fax: 27-12-4204687

${ }^{\mathrm{b}}$ Department of Chemistry, PO Box 339, University of the Free State, Bloemfontein, 9300, South Africa, Tel: 27-514012194, Fax: 27-51-4446384.

${ }^{c}$ Center for Theoretical and Computational Chemistry (CTCC), University of Troms $\emptyset$, N-9037 Troms $\varnothing$, Norway.

* Contact author details:

Name: Marilé Landman Tel: ++27-12-4202527 Fax: ++27-12-4204687, email: marile.landman@up.ac.za

Name: Jeanet Conradie, Tel: ++27-51-4012194, Fax: ++27-51-4446384, email: conradj@ufs.ac.za

\section{Table of content diagram}

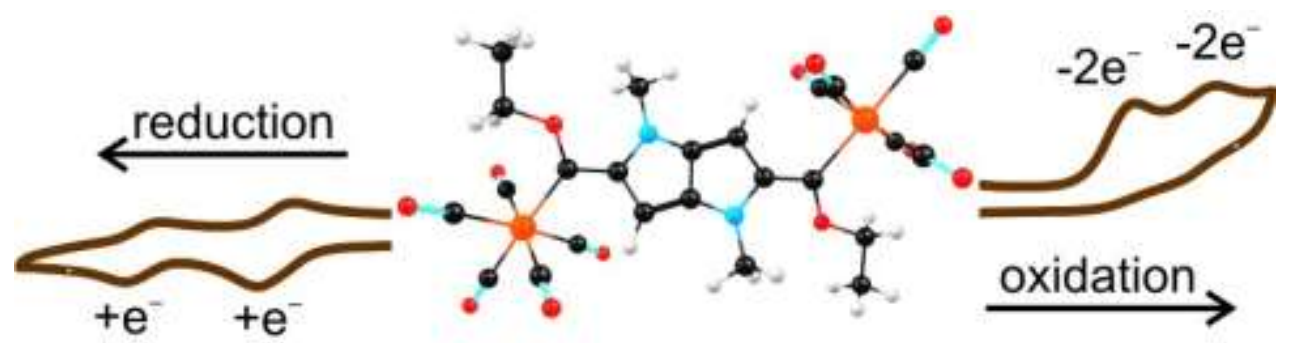

\section{Table of content briefs}

Modified mono and bis Fischer W-carbenes.

\section{Keywords}

Fischer carbene; Tungsten; Bis-carbene; Electrochemistry; DFT calculations 


\section{Abstract}

An electrochemical study of a series of mono and biscarbene complexes of tungsten pentacarbonyl with mono- and dimeric heteroarene substituents are reported and compared in $\mathrm{CH}_{3} \mathrm{CN}$ and DCM. Results revealed that the order of oxidation (reduction) depends largely on the aryl substituent attached to the carbene carbon (2-thienyl, 2-furyl or 2-(N-methylpyrrolyl)). The order of oxidation (reduction) for monocarbene complexes containing a monomeric heteroarene substituent $((\mathbf{1})-(\mathbf{3})$ ), a dimeric heteroarene substituent $((\mathbf{4})-(\mathbf{6}))$ or biscarbene complexes connected with a heteroarene substituent $((\mathbf{7})-(\mathbf{9}))$ is the same, namely 2-thienyl > 2-furyl > 2-(N-methylpyrrolyl). Carbene complexes containing a larger conjugated heteroarene substituent attached to the carbene carbon reduce more easily than the monomeric analogues. Tungsten biscarbene complexes exhibit two separate oxidation potentials for the two metal centres or one large oxidation peak, consistent with the simultaneous oxidation of the two $\mathrm{W}$ metal centres.

\section{Introduction}

Although the first Fischer carbene complex had been synthesized in 1964 already [1], the redox properties and activity of the generated radical species have only been considered more recently. Casy et. al. was the first to report experimental studies on the redox properties of group VI Fischer alkoxy carbene complexes, demonstrating the formation of a radical anion in the reduction of the carbene complex in the presence of $\mathrm{Na} / \mathrm{K}$ alloy [2]. The possibility of employing these complexes in $\mathrm{C}-\mathrm{C}$ bond formation reactions is expected, as the LUMO of electrophilic Fischer carbene complexes is carbon-centred [2]. After one electron reduction, a carbene radical is formed on the carbene carbon atom [3]. This allows for possible catalytic synthetic organic transformations. An in-depth article by Sierra et. al. explored the reactivity of Fischer carbene complexes in electron transfer processes and determined that both the nature of the metal and the stability of the radical species were important factors in determining the eventual reaction products [4].

Electrochemical studies previously reported on Fischer tungsten carbene complexes (Figure 1), focused on the influence of (a) different substituents on the carbene ligand (e.g. Y = 2-thienyl or 2furyl [5], $\mathrm{CH}_{3}$ [6], $\mathrm{Ph}$ [7], ferrocenyl [8]), (b) different heteroatom substituents ( $\mathrm{X}=\mathrm{O}$ vs $\mathrm{N}[5,6]$ ) and (c) ligand-substitution on the metal ( $\mathrm{L}=\mathrm{PPh}_{3}, \mathrm{P}(\mathrm{OPh})_{3}$, dppe (1,2bis(diphenylphosphino)ethane), the chelated product of ethylene diamine) [9] or $\eta^{2}-\mathrm{N}$-allyl-Nallylamino [7]. 


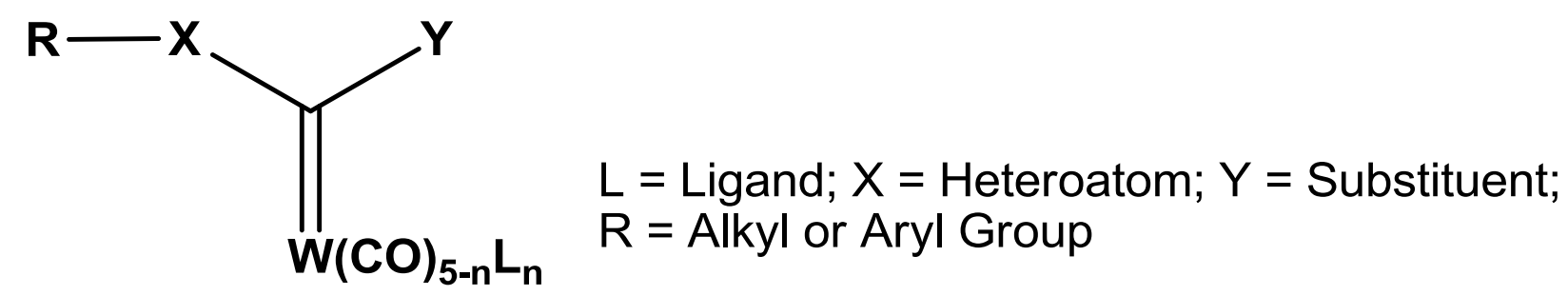

Figure 1. General structure of a Fischer carbene complex of tungsten.

In this study we focus on the influence of (d) dimeric heteroarene substituents ( $\mathrm{Y}=2,2$ '-bithienyl, 2,2'-thienylfuran, N-methyl-2-(2'-thienyl)pyrrole, N,N'-Dimethylpyrrolo[3,2-b]pyrrole and trimeric terthienyl; and (e) another pentacarbonyl carbene unit (biscarbenes) on W(0) pentacarbonyl Fischer carbene complexes. The complexes of this study are shown in Scheme 1.
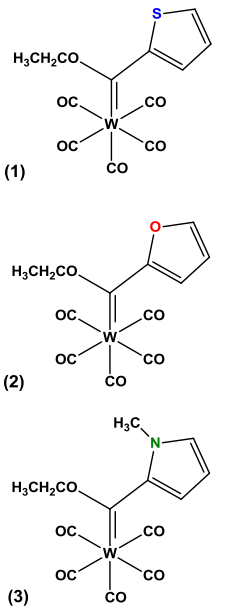

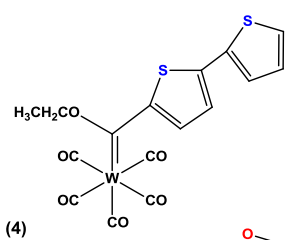

(4)

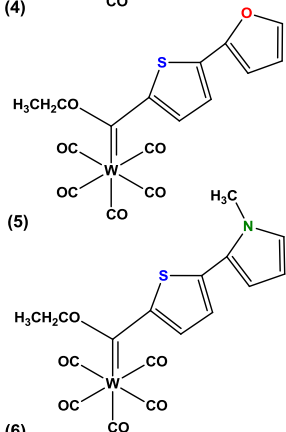

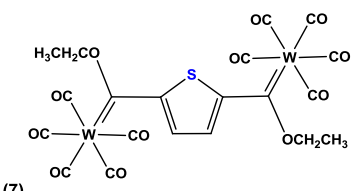

(7)
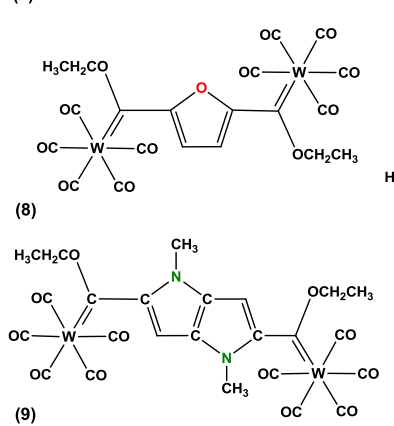
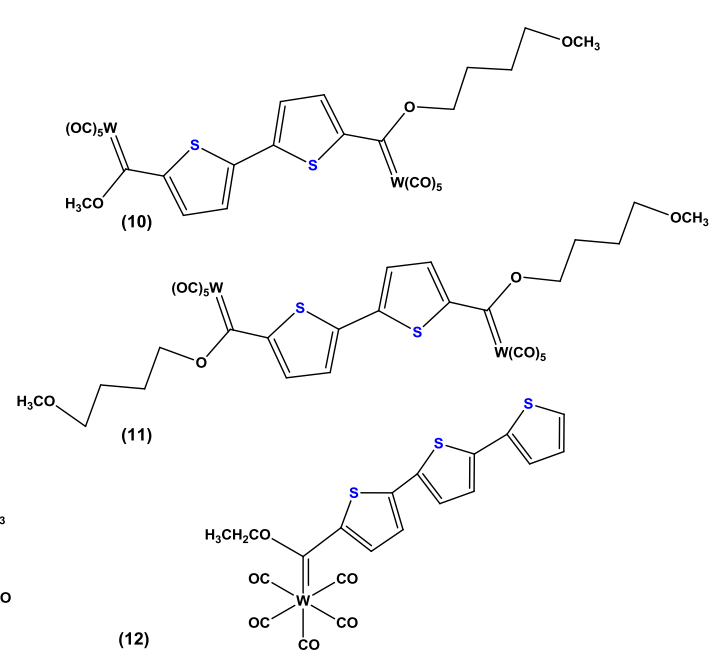

Scheme 1. Fischer mono and biscarbene complexes of tungsten with mono and dimeric heteroarene substituents: $\left[(\mathrm{CO})_{5} \mathrm{~W}=\mathrm{C}(\mathrm{OEt}) \mathrm{Ar}\right]$ with $\mathrm{Ar}=2$-thienyl (1) and (7); 2-furyl (2) and (8); 2-(N-methylpyrrolyl) (3); 2,2'-bithienyl (4), (10) and (11); 2,2'-thienylfuran (5); N-methyl-2-(2'-thienyl)pyrrole (6); N,N'-Dimethylpyrrolo[3,2-b]pyrrole (9) and terthienyl (12).

\section{Material and methods}

\section{General}

All compounds were synthesised and characterized under an inert atmosphere of argon or nitrogen gas, using standard Schlenk tube methods unless otherwise specified [10]. Solid reagents used in preparations (Merck, Aldrich and Fluka) were used without further purification. [11]. Triethyloxonium tetrafluoroborate was prepared according to a literature procedure [12]. Thiophene was purified as described in literature, prior to use [11]. The following dimeric heteroarene precursors were synthesized according to known literature methods: 2,2'-Thienylfuran (A) [13] and 
N-methyl-2-(2'-thienyl)pyrrole (B) [13]. For the carbene complexes, well-known Fischer synthetic methodology was used [1]: [W(CO) ${ }_{5} \mathrm{C}(\mathrm{OEt})\left(2\right.$-thienyl)] (1) [14], [W(CO) ${ }_{5} \mathrm{C}(\mathrm{OEt})(2$-furyl)] (2) [15],

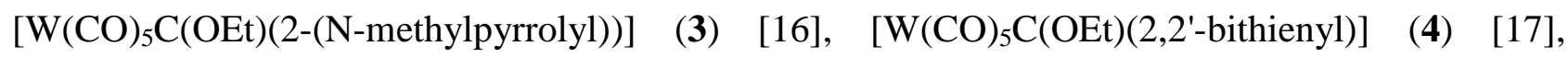
$\left[\mathrm{W}(\mathrm{CO})_{5} \mathrm{C}(\mathrm{OEt})\left(\mathrm{N}-\mathrm{methyl}^{2}-\left(2^{\prime}\right.\right.\right.$-thienyl)pyrrole $\left.)\right] \quad(\mathbf{6}) \quad[13], \quad\left[\left\{\mathrm{W}(\mathrm{CO})_{5} \mathrm{C}(\mathrm{OEt})\right\}_{2}\left(2,2^{\prime}\right.\right.$-thienyl) $\quad$ (7) [18], [\{W(CO) $\left.)_{5} \mathrm{C}(\mathrm{OEt})\right\}_{2}(2,2$ '-furyl $\left.)\right](8)$ [15], [\{W(CO) $\left.)_{5} \mathrm{C}(\mathrm{OEt})\right\}_{2}\left(2,2^{\prime}-(\mathrm{N}, \mathrm{N}\right.$-dimethylpyrrolo[3,2b]pyrrole)) $] \quad$ (9) $\quad[19], \quad\left[\left\{\mathrm{W}(\mathrm{CO})_{5} \mathrm{C}\right\}_{2}(\mathrm{OMe})\left(\mathrm{OC}_{4} \mathrm{H}_{8} \mathrm{OMe}\right)\left(2,2^{2}\right.\right.$-bithienyl) $] \quad$ (10) [13], $\left[\left\{\mathrm{W}(\mathrm{CO})_{5} \mathrm{C}\left(\mathrm{OC}_{4} \mathrm{H}_{8} \mathrm{OMe}\right)\right\}_{2}(2,2 \text { '-bithienyl)] (11) [13], [W(CO) })_{5} \mathrm{C}(\mathrm{OEt})(2\right.$-terthienyl)] (12) [20]. Characterization data of $(\mathbf{1})-(\mathbf{4}),(\mathbf{6})-(\mathbf{1 2})$ were in agreement with these literature reports, data of (5) is reported below. Infrared spectra were recorded on a Perkin-Elmer Spectrum RXI FT-IR spectrophotometer using $\mathrm{KBr}$ pellets. Nuclear magnetic resonance spectra were recorded on a Bruker AC-300 spectrometer. All the solvents were dried under an inert atmosphere of nitrogen gas following the conventional laboratory methods prior to use [21]. Chromatographic separations and purification were performed using nitrogen gas saturated kieselgel (0.063-0.200 mm).

\section{Synthesis}

$\left[\mathrm{W}(\mathrm{CO})_{5} \mathrm{C}(\mathrm{OEt}) 2,2^{\prime}\right.$-thienylfuran] (5)

2,2'-Thienylfuran (0.38 g, $2.5 \mathrm{mmol})$ was dissolved in tetrahydrofuran (THF) $(30 \mathrm{ml})$ and the solution cooled to $-20{ }^{\circ} \mathrm{C}$. $1.7 \mathrm{ml}(2.8 \mathrm{mmol})$ of a $1.6 \mathrm{M}$ solution of $\mathrm{n}-\mathrm{BuLi}$ in hexane was added and the reaction mixture stirred for 30 minutes. The temperature of the cold bath was lowered to -40 ${ }^{\circ} \mathrm{C}$ and $\mathrm{W}(\mathrm{CO})_{6}(0.88 \mathrm{~g}, 2.5 \mathrm{mmol})$ was added in small portions. An immediate colour change was observed to dark brown. The mixture was stirred for a further 30 minutes after which time the cold bath was removed and the brown reaction mixture stirred at room temperature for $1 \mathrm{~h}$. The solvent was removed in vacuo. The brown residue was dissolve in dichloromethane and the reaction mixture cooled to $-20{ }^{\circ} \mathrm{C}$. $0.10 \mathrm{~g}$ (2.5 mmol) $\mathrm{Et}_{3} \mathrm{OBF}_{4}$, dissolved in $15 \mathrm{ml}$ of dichloromethane (DCM), was added. The reaction mixture was stirred in the cold for $30 \mathrm{~min}$ and for a further $30 \mathrm{~min}$ at room temperature. The solvent was removed in vacuo. The residue was purified by column chromatography. The target complex was eluted from the column using hexane.

Complex (5): Yield = 76\%; Red-orange colour. ${ }^{1} \mathrm{H}$ NMR $\left(\delta(\mathrm{ppm}), \mathrm{J}(\mathrm{Hz}), \mathrm{CDCl}_{3}\right)$ : $\mathrm{H} 88.10(\mathrm{~d}), 4.4$ Hz; H9 7.33 (d), 4.4 Hz; H12 6.81 (dd), 3.5, 0.7 Hz; H13 6.51 (dd), 3.5, 1.8 Hz; H14 7.51 (dd) 1.8, $0.7 \mathrm{~Hz}$; H15 4.95 (q), $7.1 \mathrm{~Hz}$; H15 1.63 (t), 7.1 Hz. ${ }^{13} \mathrm{C}$ NMR ( $\left.(\mathrm{ppm}), \mathrm{CDCl}_{3}\right)$ : C6 286.6, W(CO) 202.6, 197.7, C8 142.7, C9 123.9, C12 109.7, C13 112.8, C14 143.9, C15 76.3, C16 15.2. IR (cm ${ }^{-1}$, $\mathrm{KBr}): 2063 \mathrm{~m}\left(\mathrm{~A}^{\prime \prime}\right), 1935 \mathrm{~s}\left(\mathrm{~A}_{1}^{\prime}\right), 1911$ vs $(\mathrm{E})$. 


\section{Crystallography}

Data for (3) and (5) were collected at $150 \mathrm{~K}$ on a Bruker D8 Venture kappa geometry diffractometer, with duo I $\mu$ s sources, a Photon 100 CMOS detector and APEX II [22] control software using Quazar multi-layer optics monochromated, Mo-Ka radiation by means of a combination of $\phi$ and $\omega$ scans. Data reduction was performed using SAINT+ [22] and the intensities were corrected for absorption using SADABS [22]. The structure was solved by intrinsic phasing using SHELXTS [23] and refined by full-matrix least squares using SHELXTL [23] and SHELXL-2012 [23]. In the structure refinement all hydrogen atoms were added in calculated positions and treated as riding on the atom to which they are attached. All non-hydrogen atoms were refined with anisotropic displacement parameters, all isotropic displacement parameters for hydrogen atoms were calculated as $\mathrm{X} \times$ Ueq of the atom to which they are attached, $\mathrm{X}=1.5$ for the methyl hydrogens and 1.2 for all other hydrogens. Compound (5) crystallized as a twin crystal and was refined as such. The crystal data, data collection, structure solution and refinement details are available in each CIF. The crystallographic data for (3) and (5) are given in the supplementary material. ORTEP drawings [24] of the two structures are included in Figure 2 and Figure 3, showing the numbering system used with ADP's at the 50\% probability level.

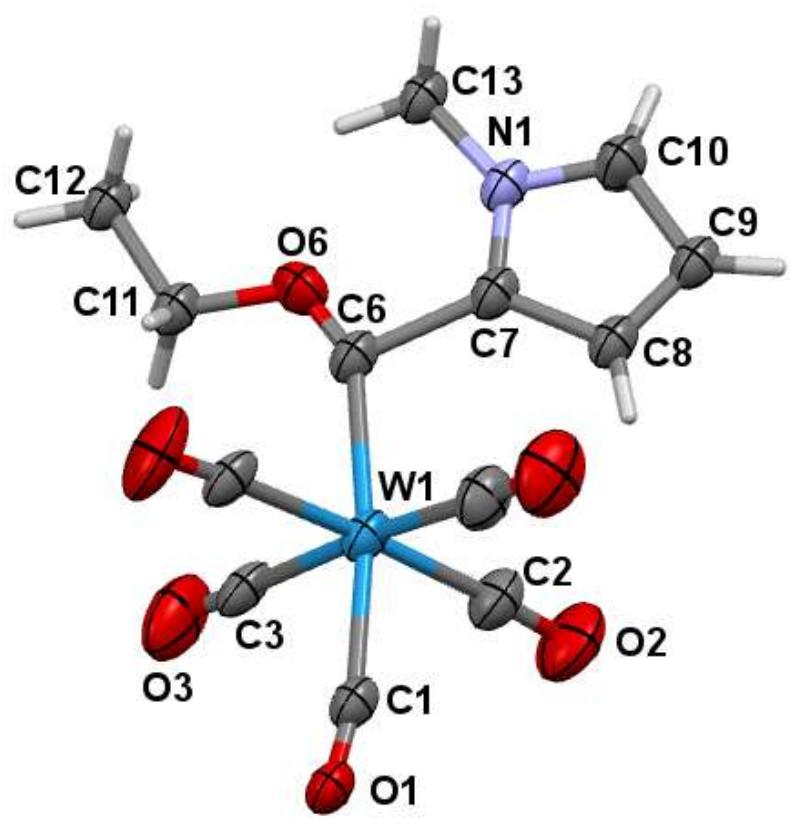

Figure 2. Perspective view of (3) with thermal ellipsoids drawn at the $50 \%$ probability level. 


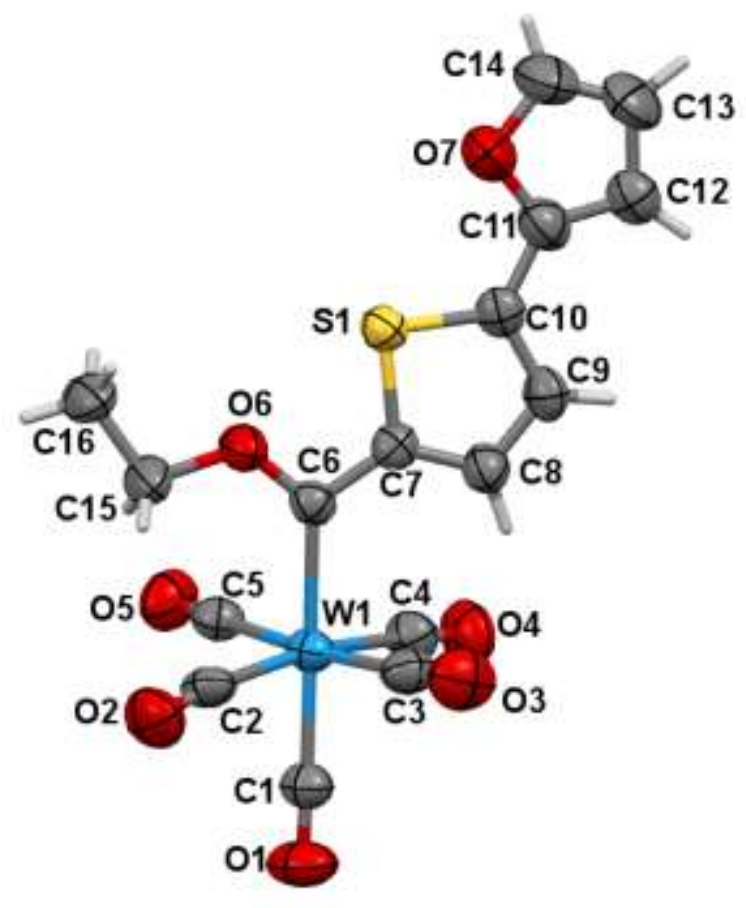

Figure 3. Perspective view of (5) with thermal ellipsoids drawn at the $50 \%$ probability level.

\section{Cyclic Voltammetry}

Cyclic voltammogram (CV), square-wave voltammetry (SW) and linear sweep voltammogram (LSV) measurements were performed on $0.0005 \mathrm{~mol} \mathrm{dm}^{-3}$ compound solutions in dry acetonitrile containing $0.1 \mathrm{~mol} \mathrm{dm}{ }^{-3}$ tetra- $n$-butylammonium hexafluorophosphate, $\left(\left[{ }^{\mathrm{n}}\left(\mathrm{Bu}_{4}\right) \mathrm{N}\right]\left[\mathrm{PF}_{6}\right]\right)$, as supporting electrolyte and under a blanket of purified argon at $25{ }^{\circ} \mathrm{C}$ utilizing a BAS 100B/W voltammograph. All CVs were also obtained in dichloromethane (DCM) as solvent. A threeelectrode cell, with a glassy carbon (surface area $7.07 \times 10^{-6} \mathrm{~m}^{2}$ ) working electrode, Pt auxiliary electrode and an $\mathrm{Ag}$ wire reference electrode were used [25]. Scan rates were 0.050-5.000 $\mathrm{V} \mathrm{s}^{-1}$. Successive experiments under the same experimental conditions showed that all oxidation and formal reduction potentials were reproducible within $10 \mathrm{mV}$. All cited potentials were referenced against the $\mathrm{FcH} / \mathrm{FcH}^{+}$couple as suggested by IUPAC [26]. Ferrocene $(\mathrm{FcH})$ exhibited a peak separation $\Delta E_{\mathrm{p}}=E_{\mathrm{pa}}-E_{\mathrm{pc}}=0.069 \mathrm{~V}$ and $i_{p c} / i_{p a}=1.00$ under our experimental conditions. $E_{\mathrm{pa}}\left(E_{\mathrm{pc}}\right)$ $=\operatorname{anodic}\left(\right.$ cathodic) peak potential and $i_{p a}\left(i_{p c}\right)=\operatorname{anodic}\left(\right.$ cathodic) peak current. $E^{\circ 1}\left(\mathrm{FcH} / \mathrm{FcH}^{+}\right)=$ $0.66(5) \mathrm{V}$ vs SHE in $\left[{ }^{\mathrm{n}}\left(\mathrm{Bu}_{4}\right) \mathrm{N}\right]\left[\mathrm{PF}_{6}\right] / \mathrm{CH}_{3} \mathrm{CN}$ and 0.77(5) $\mathrm{V}$ vs SHE in $\left[{ }^{\mathrm{n}}\left(\mathrm{Bu}_{4}\right) \mathrm{N}\right] / \mathrm{DCM}$ [27]. Decamethyl ferrocene $\left(\mathrm{Fc}^{*},-0.508 \mathrm{~V}\right.$ vs $\mathrm{FcH} / \mathrm{FcH}^{+}$in $\left[{ }^{\mathrm{n}}\left(\mathrm{Bu}_{4}\right) \mathrm{N}\right]\left[\mathrm{PF}_{6}\right] / \mathrm{CH}_{3} \mathrm{CN}$ and -0.551 vs $\mathrm{FcH} / \mathrm{FcH}^{+}$in $\left.\left[{ }^{\mathrm{n}}\left(\mathrm{Bu}_{4}\right) \mathrm{N}\right]\left[\mathrm{PF}_{6}\right] / \mathrm{DCM}\right)$ were used as internal standard. 


\section{DFT calculations}

Density functional theory (DFT) calculations of this study were performed with the hybrid functional B3LYP [28,29] (and UB3LYP for radical cations or anions) as implemented in the Gaussian 09 program package [30]. Geometries of the neutral and charged complexes were optimized in gas phase with the triple- $\zeta$ basis set $6-311 \mathrm{G}(\mathrm{d}, \mathrm{p})$ on all atoms except tungsten, where def2tzvpp [31] was used.

\section{Results and discussion}

\section{Synthesis, Characterisation and X-ray crystallography}

The detailed synthesis and characterization of most of the complexes of this study have been reported previously [13-20]. Complex (5) was synthesized according to the analogous methoxy complex reported in literature [13] and characterization data are similar. The two crystal structures of (3) and (5) are shown in Figure 2 and Figure 3.

Table 1. Selected geometric parameters for (3) and (5)

\begin{tabular}{|c|c|c|}
\hline Complexes & 3 & 5 \\
\hline \multicolumn{3}{|l|}{ Bond length $(\AA)$} \\
\hline W1-C6 & $2.234(19)$ & $2.200(13)$ \\
\hline W1-C1 & $2.058(17)$ & $2.001(13)$ \\
\hline W1-Ccis(ave) & $2.03(4)$ & $2.056(15)$ \\
\hline C6-O6 & $1.13(3)$ & $1.319(16)$ \\
\hline C6-C7 & $1.56(2)$ & $1.446(18)$ \\
\hline \multicolumn{3}{|l|}{ Bond angle $\left(^{\circ}\right)$} \\
\hline W1-C6-O6 & $144.8(16)$ & 129.2(9) \\
\hline W1-C6-C7 & $111.7(15)$ & $124.8(9)$ \\
\hline O6-C6-C7 & $103.5(15)$ & $106.0(10)$ \\
\hline \multicolumn{3}{|l|}{ Torsion angle $\left(^{\circ}\right)$} \\
\hline O6-C6-C7-N1/S1 & $0.000(3)$ & $-1.4(13)$ \\
\hline W1-C6-C7-N1/S1 & $180.000(2)$ & $177.0(5)$ \\
\hline
\end{tabular}

Selected structural parameters of importance are summarized in Table 1. Both complexes crystallized in the syn conformations observed for the heteroatom orientation of the two carbene substituents. This W-C(carbene) distance of 2.234(19) $\AA$ in (3) is similar to that observed in (5), 2.200(13) $\AA$, although the W1-C1 bond (trans W-C(carbene)) distances differed by $0.057 \AA$, the shorter distance being observed in (3). The carbene substituents in both (3) and (5) are planar, and 
in both compounds bisect the $\mathrm{O}=\mathrm{C}=\mathrm{W}=\mathrm{C}=\mathrm{O}$ bonds by $46^{\circ}(\mathrm{C} 3-\mathrm{W} 1-\mathrm{C} 6-\mathrm{O} 6)$ and $54^{\circ}$ (C5-W1-C6O6) respectively. There is an unusually large discrepancy in the size of the W1-C6-O6 angles. The angle observed in $(3)\left(144.8(16)^{\circ}\right)$ reflects the shorter O6...N1 distance of $2.598 \AA$ when compared with the distance of $2.660 \AA$ observed in (5). Furthermore, in compound 3 a hydrogen bond of $2.048 \AA$ is observed between O6 and H13A. This may account for the significant distortion of the bond angles around the carbene carbon atom, C6 (see Table 1).

\section{CV and DFT study}

The electrochemical studies presented here were carried out in $\mathrm{CH}_{3} \mathrm{CN}$ with $0.1 \mathrm{~mol} \mathrm{dm}^{-3}$ $\left[{ }^{\mathrm{n}}\left(\mathrm{Bu}_{4}\right) \mathrm{N}\right]\left[\mathrm{PF}_{6}\right]$ as supporting electrolyte. Due to the poor solubility of some of the complexes, the studies were repeated in dichloromethane (DCM) as solvent. DFT calculations on the neutral and charged species support the experimental observation. The voltammograms of carbene complexes (1) - (12) of this study are given in Figure 4 and the data summarized in Error! Reference source not found. (data of complexes (1) and (2) in $\mathrm{CH}_{3} \mathrm{CN}$ are from reference [5]). The main redox events generally observed for $(\mathbf{1})-(\mathbf{1 2})$, are an oxidation process at potentials higher than $0.2 \mathrm{~V}$ versus $\mathrm{Fc} / \mathrm{Fc}^{+}$, and a

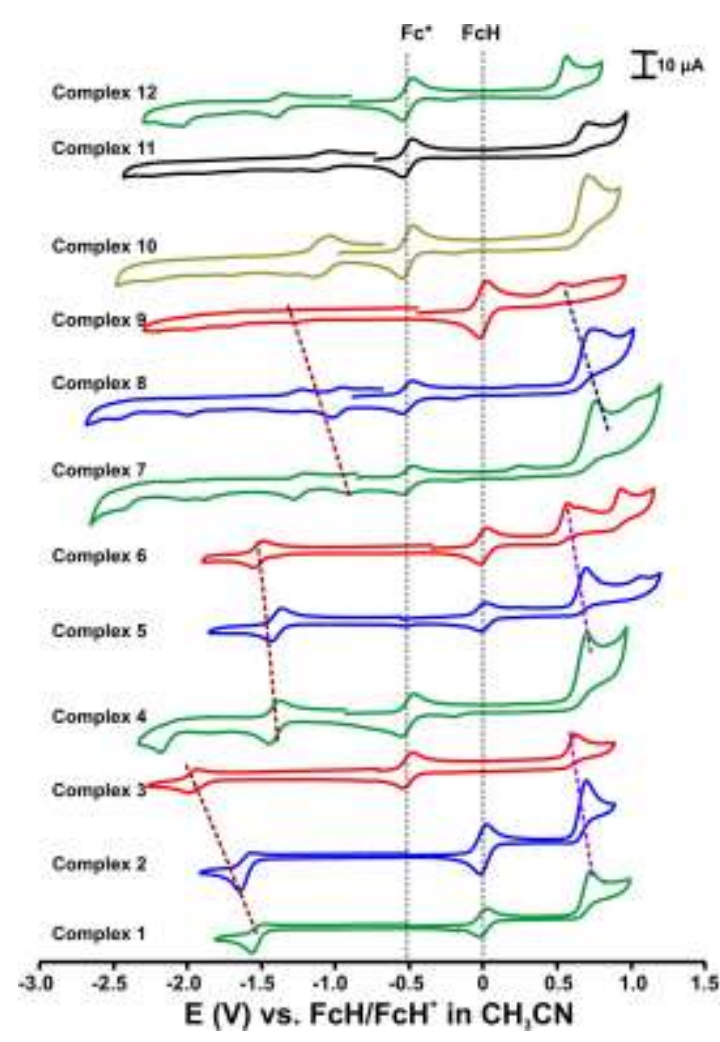

(a)

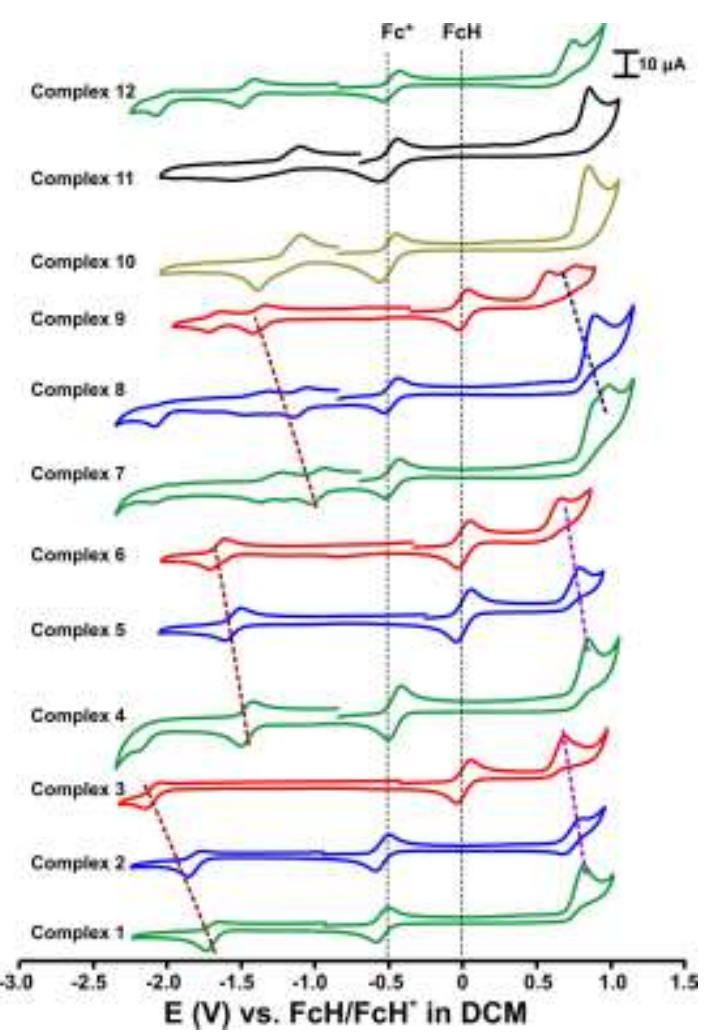

(b)

Figure 4. Cyclic voltammograms of ca. $0.0005 \mathrm{~mol} \mathrm{dm}^{-3}$ solutions of (1) - (12) in (a) $\mathrm{CH}_{3} \mathrm{CN} / 0.1 \mathrm{~mol} \mathrm{dm}^{-3}$ $\left[{ }^{\mathrm{n}}\left(\mathrm{Bu}_{4}\right) \mathrm{N}\right]\left[\mathrm{PF}_{6}\right]$ and (b) $\mathrm{DCM} / 0.1 \mathrm{~mol} \mathrm{dm}{ }^{-3}\left[{ }^{\mathrm{n}}\left(\mathrm{Bu}_{4}\right) \mathrm{N}\right]\left[\mathrm{PF}_{6}\right]$, on a glassy carbon-working electrode at a scan rate of 
$0.100 \mathrm{~V} \mathrm{~s}^{-1}$. CV peaks due to the internal standard used, are marked Fc* (decamethyl ferrocene ) or FcH (ferrocene). Scans initiated in the positive direction, starting to the left of the internal standard.

reduction process at potentials lower than $-1.0 \mathrm{~V}$ versus $\mathrm{Fc} / \mathrm{Fc}^{+}$. Computational chemistry studies on tungsten carbene complexes presented by us [5,9] and other researchers [6,7], showed that the oxidation process involves a two electron $\mathrm{W}$-metal based oxidation and that the one electron reduction occurs at the carbene carbon with the formation of a radical anion with electron density distributed over the carbene ligand.

The oxidation peaks for $(\mathbf{1})$ - (12) are considered irreversible, since no reduction peak related to the reduction of the oxidized species is observed, not even at scan rates as high as $1 \mathrm{~V} \mathrm{~s}^{-1}$, see Figure 5 for $(\mathbf{3})$ as example. The reduction peaks for $(\mathbf{1})-(\mathbf{9}),(\mathbf{1 2})$ are considered to be electrochemically reversible since the re-oxidation peak intensifies at higher scan rates with peak current separation of less than $0.090 \mathrm{~V}$. The reduction of (10) and (11) with peak current separation of ca. $0.115 \mathrm{~V}$ is considered electrochemically quasi reversible. Electrochemical reversible redox processes are characterized by a peak potential separation of $0.059 \mathrm{~V}\left(\Delta E=E_{\mathrm{pa}}-E_{\mathrm{pc}}\right) . \Delta E_{\mathrm{p}}$ values up to $0.090 \mathrm{~V}$ is generally considered as indicative of an electrochemically reversible couple, since the experimental peak separation is often found to be larger than the Nernstian value of $0.059 \mathrm{~V}$ (for a one electron process) due to uncompensated ohmic drops in the cell [32,33]. Chemical reversible redox processes are characterized by a peak current ratio $i_{\mathrm{pc}} / i_{\mathrm{pa}}=1$ (when the diffusion coefficients of the oxidized and reduced forms of the couple are identical or near identical) [34-36].

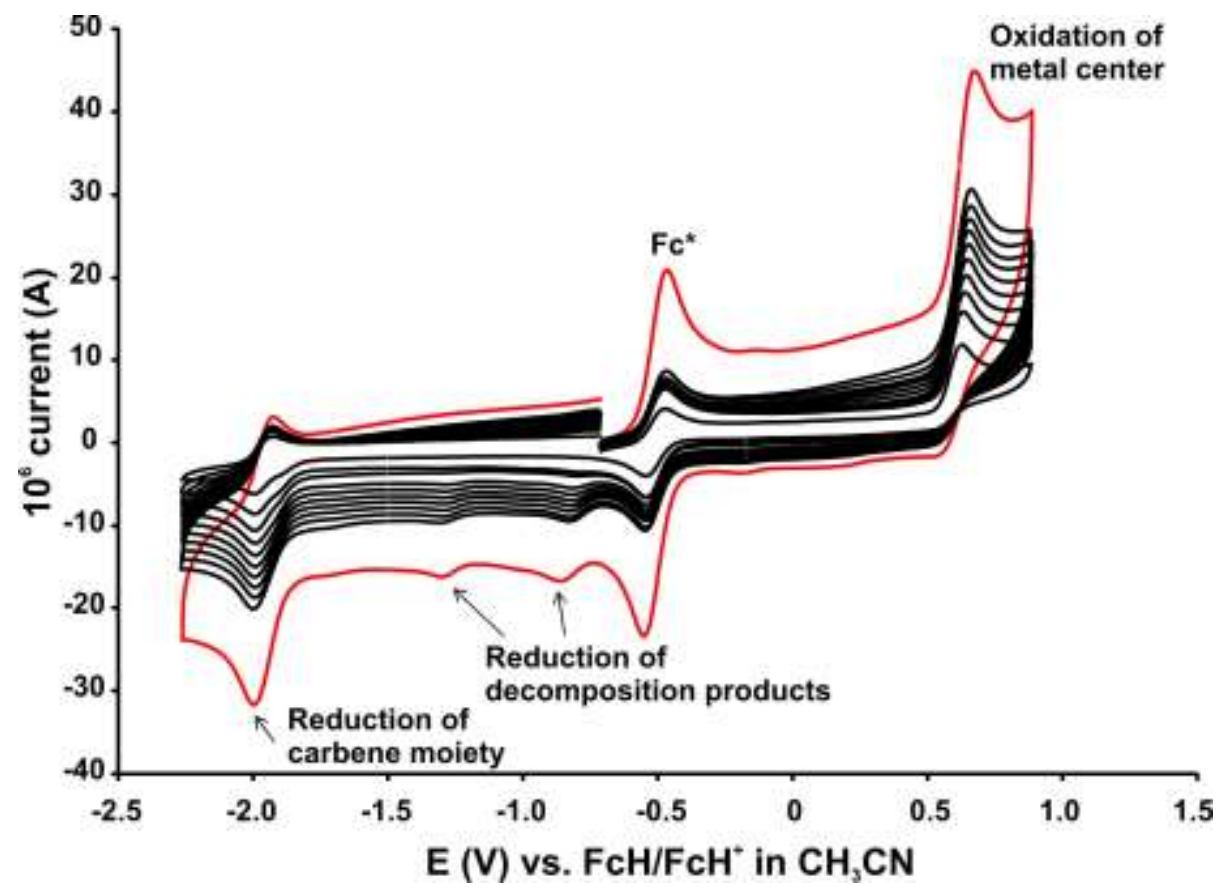

Figure 5. Cyclic voltammograms of ca. $0.0005 \mathrm{~mol} \mathrm{dm}^{-3}$ solutions of $(\mathbf{3})$ in $\mathrm{CH}_{3} \mathrm{CN} / 0.1 \mathrm{~mol} \mathrm{dm}^{-3}\left[{ }^{\mathrm{n}}\left(\mathrm{Bu}_{4}\right) \mathrm{N}\right]\left[\mathrm{PF}_{6}\right]$ on a glassy carbon-working electrode at a scan rate of at scan rates of 0.050 (smallest currents) till $0.500 \mathrm{~V} \mathrm{~s}^{-1}$ in $0.050 \mathrm{~V}$ increments, $1.000 \mathrm{~V} \mathrm{~s}^{-1}$ (indicated in red). Decamethylferrocene, Fc* was used as internal standard. The small reduction 
peaks are ascribed to decomposition products that are generated during $\mathrm{W}$ oxidation since these peaks are absent if the scans are initiated in the negative direction. Scans initiated in the positive direction from $-0.700 \mathrm{~V}$.

The profile of the oxidation and reduction processes obtained in $\mathrm{CH}_{3} \mathrm{CN}$ and DCM as solvent, are similar, although the electrochemical HOMO-LUMO gap, the difference between the W-oxidation

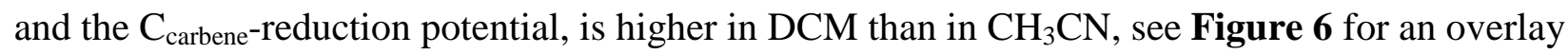

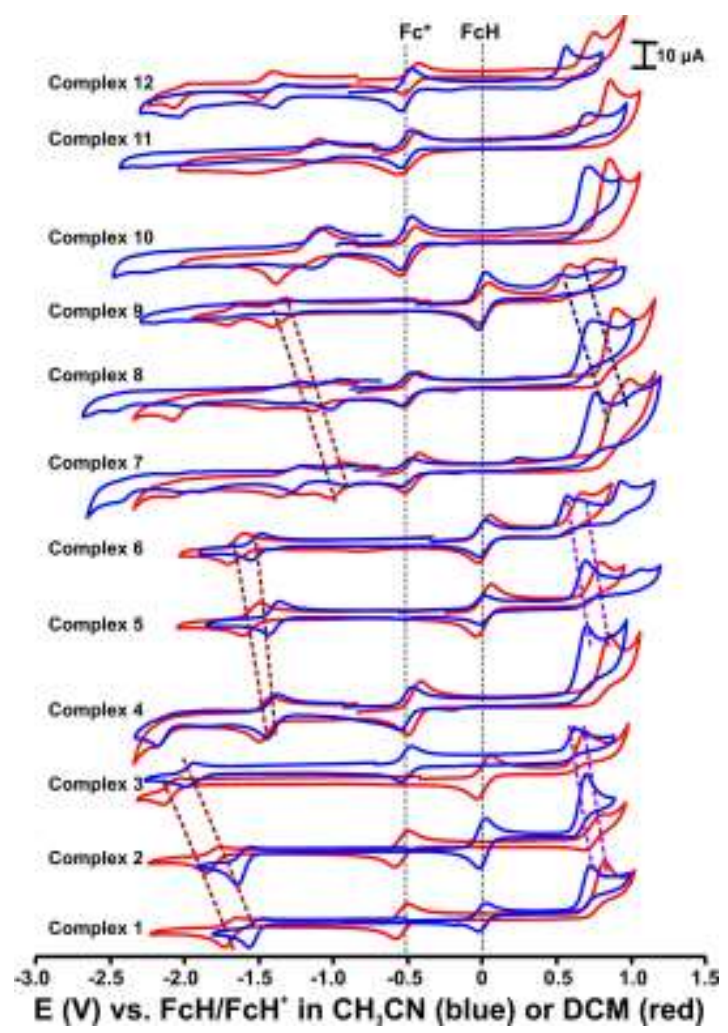

Figure 6. Overlay of the cyclic voltammograms of (1) - (12) in $\mathrm{CH}_{3} \mathrm{CN}$ (blue) and DCM (red) with $0.1 \mathrm{~mol} \mathrm{dm}^{-3}$ $\left[{ }^{\mathrm{n}}\left(\mathrm{Bu}_{4}\right) \mathrm{N}\right]\left[\mathrm{PF}_{6}\right]$ as electrolyte, on a glassy carbon-working electrode at a scan rate of $0.100 \mathrm{~V} \mathrm{~s}^{-1}$. The peaks indicated with $\mathrm{Fc}^{*}$ and $\mathrm{FcH}$ are due to the internal standard. (For interpretation of the references to color in text, the reader is referred to the web version of this article.)

of the $\mathrm{CVs}$ in $\mathrm{CH}_{3} \mathrm{CN}$ and DCM. The peak oxidation potential, $E_{\mathrm{pa}}$, of the oxidation process in DCM is $0.05-0.20 \mathrm{~V}$ higher (more positive) than $E_{\mathrm{pa}}$ in $\mathrm{CH}_{3} \mathrm{CN}$, while the reduction process in DCM is observed at a potential more than $0.05-0.43 \mathrm{~V}$ lower (more negative) than in $\mathrm{CH}_{3} \mathrm{CN}$. This result is in agreement with the reported formal oxidation potential of ferrocene that is $0.11 \mathrm{~V}$ higher (more positive) in DCM than in $\mathrm{CH}_{3} \mathrm{CN}$ as solvent [27]. The algebraic difference between the first oxidation and reduction potentials is reflected in the DFT calculated HOMO-LUMO gaps of complexes (1) - (9), (12), see Figure 7 with the data summarized in Error! Reference source not found. The biscarbene complexes (10) and (11) deviated from the fit, with oxidation potentials similar to the oxidation potential of (1). 


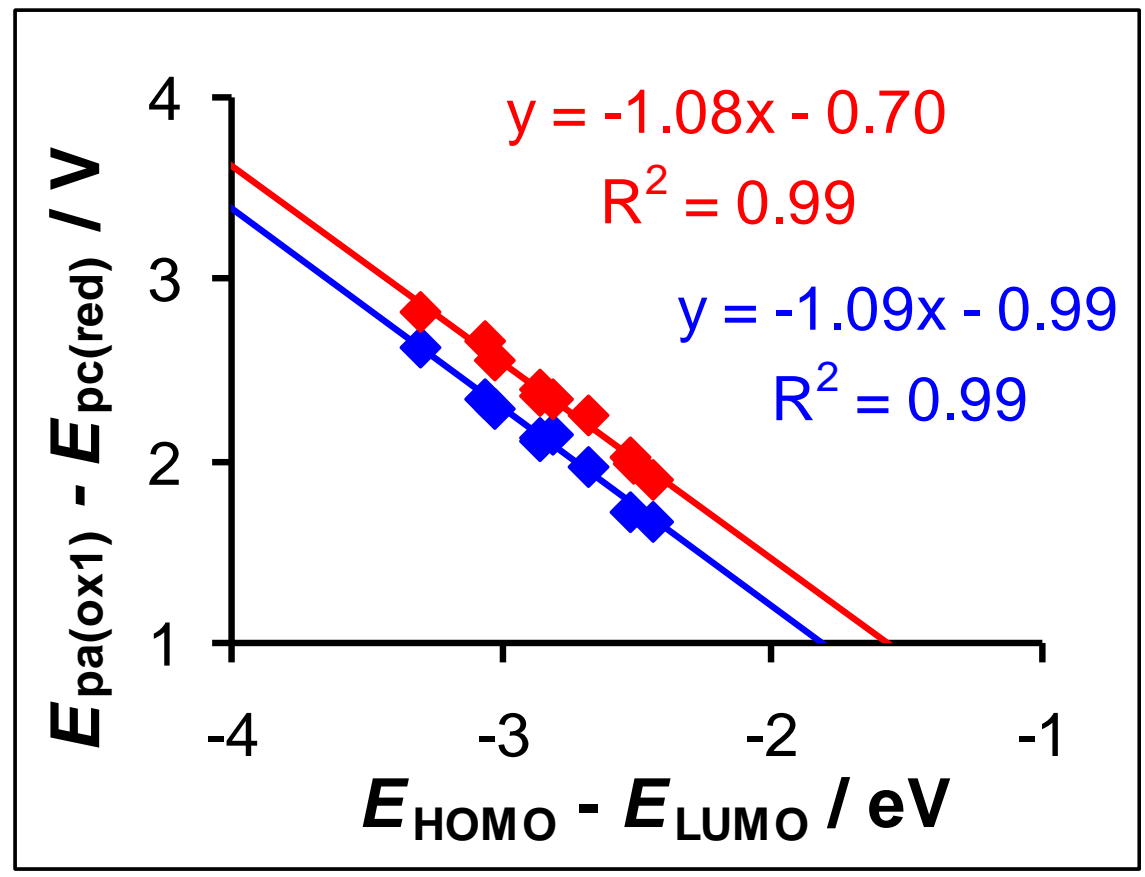

Figure 7. Linear correlations between the electrochemical HOMO-to-LUMO gaps ( $E_{\mathrm{pa}}$ of the oxidation process - $E_{\mathrm{pc}}$ of the reduction process) and the DFT calculated HOMO-LUMO gaps of complexes of (1) - (9) and (12). Electrochemical data in $\mathrm{CH}_{3} \mathrm{CN}$ (blue, bottom) and DCM (red, top). Data are summarized in Error! Reference source not found..

\section{Tungsten monocarbene complexes with monomeric heteroaromatic substituents, 1 - 3}

Complexes (1) - (3) can be used to study the influence of the five-membered heteroaromatic rings on the carbene ligand: 2-thienyl (1), 2-furyl (2) and 2-(N-methylpyrrolyl) (3). The oxidation potential of the oxidation process decreases (becomes less positive) for $\left[\mathrm{W}(\mathrm{CO})_{5}\{\mathrm{C}(\mathrm{OEt}) \mathrm{Ar}\}\right]$ with substitution of the aryl group from 2-thienyl (1) to 2-furyl (2) and 2-(N-methylpyrrolyl) (3). The same trend is observed for the reduction potential of the reduction of the carbene ligand (more negative). This trend is not in the order of the electronegativity of the $\mathrm{O}(3.44)>\mathrm{N}(3.04)>\mathrm{S}$ (2.58), although it is possible that the $\mathrm{CH}_{3}$ group $\left(\chi_{\mathrm{CH} 3}=2.34\right.$ [37]) donates electron density to $\mathrm{N}$, rendering $\left(\mathrm{NCH}_{3}\right)$ less electronegative than $\mathrm{N}$ and possibly than $\mathrm{S}$. Connor and Jones [38] studied a number of heteroaromatic chromium carbene complexes $(\mathrm{CO})_{5} \mathrm{CrC}(\mathrm{Y}) \mathrm{X}$ to determine the extent to which the electron-donating ability of the heteroaromatic ring aids in stabilizing the empty p-orbital on the carbene carbon atom. The order of increasing electron-donating ability was found to be $\mathrm{Y}=$ 2 -furyl $<2$-thienyl $<2$-(N-methylpyrrolyl). This implies that the 2-(N-methylpyrrolyl) ring donates more electron density, in this case via conjugation to $\mathrm{W}$, making $\mathrm{W}$ in complex $\mathbf{3}$ relatively more electron rich and thus easier to oxidise (at a lower less positive potential) than $\mathrm{W}$ in complex (1) or (2). The order observed for the oxidation of (1) with a 2-thienyl group versus (2) with a 2-furyl group is discussed previously [5]: "The same "reverse" trend is obtained for the oxidation potential 
of the related $\mathrm{Cr}$-alkoxycarbene complexes $\left[\mathrm{Cr}(\mathrm{CO})_{5}\{\mathrm{C}(\mathrm{OEt}) \mathrm{Ar}\}\right], \mathrm{Ar}=$ thienyl $\left(E^{0^{\prime}}=496 \mathrm{mV}\right)$ or furyl $\left(E^{0^{\prime}}=454 \mathrm{mV}\right)[9,39]$ and for the $\mathrm{Ti}^{\mathrm{IV} / \mathrm{III}}$ couple of $\beta$-diketonato-titanocene complexes $\left[\mathrm{Cp}_{2} \mathrm{Ti}\left(\mathrm{CF}_{3} \mathrm{COCHCOR}\right)\right]^{+}$with $\mathrm{Cp}=$ cyclopentadienyl and $\mathrm{R}=$ thienyl $\left(E^{0^{\prime}}=-619 \mathrm{mV}\right)$ or furyl $\left(E^{0^{\prime}}\right.$ $=-625 \mathrm{mV}$ ) [40]. On the other hand, the oxidation potential for Cr-aminocarbene complexes $\left[\mathrm{Cr}(\mathrm{CO})_{5}\left\{\mathrm{C}\left(\mathrm{NH}_{2}\right) \mathrm{Ar}\right\}\right], \mathrm{Ar}=$ thienyl or furyl were the same [39] while for Cr-aminocarbene complexes $\left[\mathrm{Cr}(\mathrm{CO})_{5}\left\{\mathrm{C}\left(\mathrm{N}\left(\mathrm{CH}_{3}\right)_{2}\right) \mathrm{Ar}\right\}\right]$, the oxidation potential of the complex with $\mathrm{Ar}=$ thienyl < $\mathrm{Ar}=$ furyl [41]. These results show that the electronegativity of $\mathrm{O}$ and $\mathrm{S}$ alone, cannot forecast the order of oxidation of thienyl or furyl-containing complexes" [5].

\section{Tungsten carbene complexes with dimeric heteroaromatic substituents, 4 - 6}

Complexes (4) - (6) each contain a dimeric heteroaromatic ring, the first ring directly bonded to the carbene carbon a thienyl, and the second ring 2-thienyl (4), 2-furyl (5) and 2-(N-methylpyrrolyl) (6). Both the oxidation potential of the $\mathrm{W}$-metal oxidation and the reduction potential of the carbene ligand reduction of $(\mathbf{4})$ - (6) follow the same order as was found for $(\mathbf{1})-(\mathbf{3})$, see the dotted lines in Figure 4. The same order of oxidation and reduction is also found for the biscarbene complexes (7) - (9), where the two $\mathrm{W}(\mathrm{CO})_{5}=\mathrm{C}(\mathrm{OEt})$ units are connected with a heteroaromatic ring(s), 2-thienyl (7), 2-furyl (8) and 2-(N,N'-dimethylpyrrolo[3,2-b]pyrrolyl) (9).

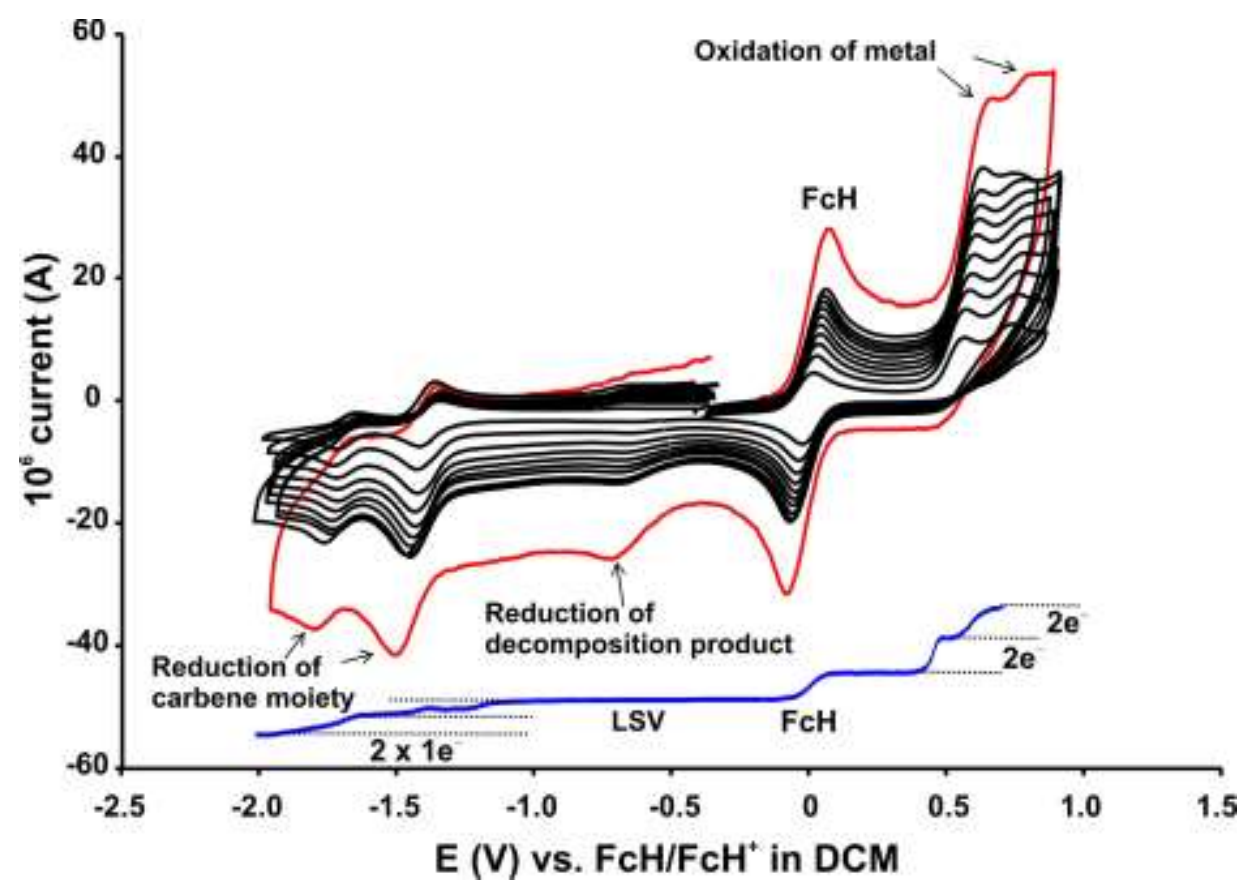

Figure 8. Cyclic voltammograms of $c a .0 .0005 \mathrm{~mol} \mathrm{dm}^{-3}$ solutions of the bis-metal-W-carbene complex (9) in DCM / $0.1 \mathrm{~mol} \mathrm{dm}^{-3}\left[{ }^{\mathrm{n}}\left(\mathrm{Bu}_{4}\right) \mathrm{N}\right]\left[\mathrm{PF}_{6}\right]$ on a glassy carbon-working electrode at a scan rate of at scan rates of 0.050 (smallest currents) till $0.500 \mathrm{~V} \mathrm{~s}^{-1}$ in $0.050 \mathrm{~V}$ increments, $1.000 \mathrm{~V} \mathrm{~s}^{-1}$ (indicated in red). Ferrocene, FcH was used as internal standard. The small reduction peaks are ascribed to a decomposition product that are generated during $\mathrm{W}$ oxidation since these peaks are absent if the scans are initiated in the negative direction. Scans initiated in the positive direction from $-0.400 \mathrm{~V}$. 


\section{Tungsten biscarbene complexes, 7 - 11}

For each of the biscarbene complexes (7) - (9), two oxidation and two or more reduction processes are observed, see Figure 8 for an overlay of various scan rates for (9) in DCM as example (100 mV $\mathrm{s}^{-1}$ scans of (7) - (9) is in Figure 4). The linear sweep voltammogram (LSV) for (9) shown in Figure 8 indicates two $2 \mathrm{e}^{-}$oxidation processes and two $1 \mathrm{e}^{-}$reduction processes. The first oxidation process is interpreted as the $2 \mathrm{e}^{-}$oxidation of the one metal centre and the second oxidation as the $2 \mathrm{e}^{-}$oxidation of the second metal centre. Different oxidation potentials for two similar redox active centers in the same molecule are often observed in systems that allow electron delocalization [42]. Once the first $\mathrm{W}$-centre is oxidized to $\mathrm{W}(\mathrm{II})$, it withdraws electron density via conjugation from the other $\mathrm{W}$-centre. The other $\mathrm{W}$-centre thus becomes more positive and relative more difficult to oxidize than the first $\mathrm{W}$-centre. This interpretation is also consistent with the fact that the HOMO (closed shell, containing an $\alpha$ and a $\beta \mathrm{d}_{\pi}$ electrons) of the DFT calculated optimized neutral geometry of (7) - (9), lies on the one W and the HOMO-1 (closed shell, containing an $\alpha$ and a $\beta \mathrm{d}_{\pi}$ electrons) on the other W-centre, see Figure 9 for (7) as example. The character of the HOMO
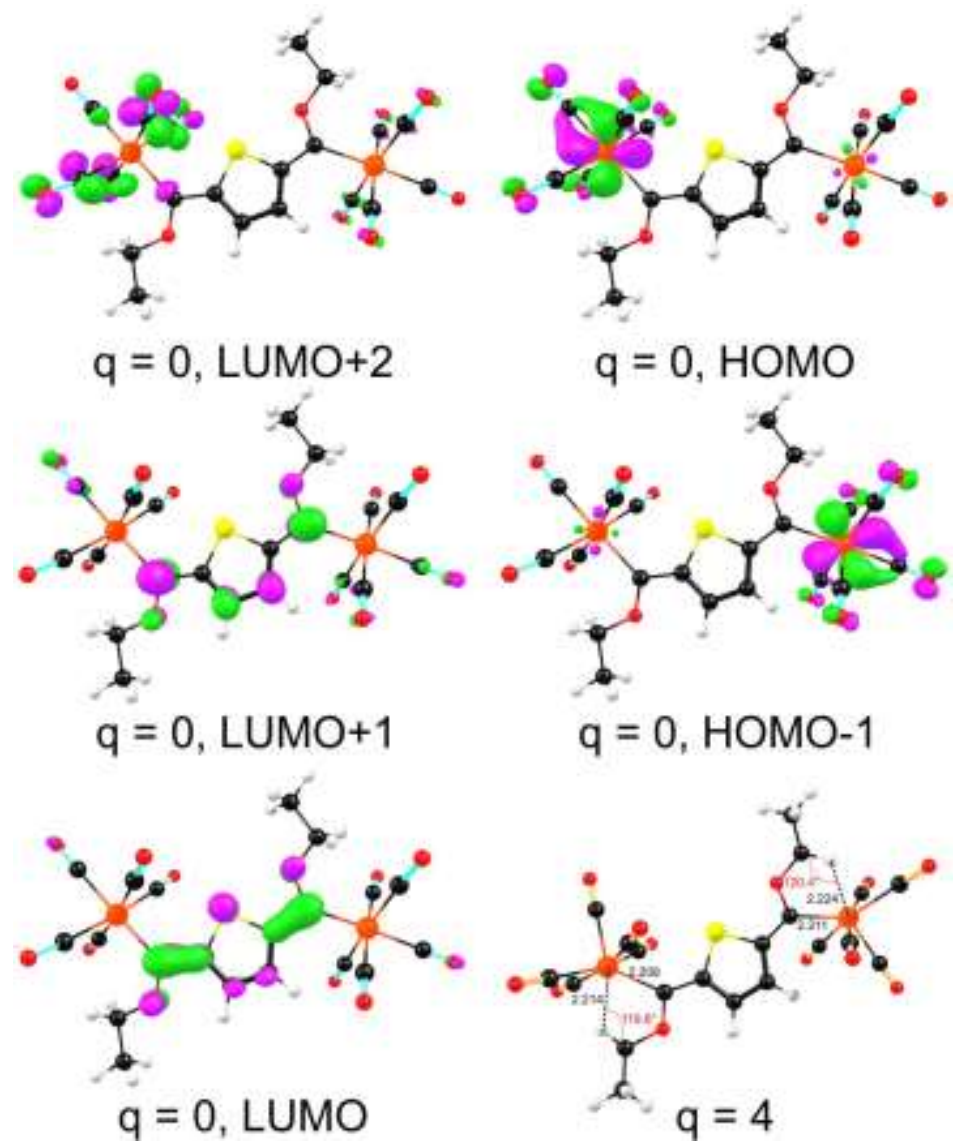

Figure 9. DFT calculated frontier MOs complex (7) with $q=0$ and structure of $q=4$. Each MO contains an $\alpha$ and a $\beta$ electron. The MO plots use a contour of $60 \mathrm{e} / \mathrm{nm}^{3}$. Bottom right: The geometry of the $\mathrm{q}=4$ complex, highlighting the agostic $\mathrm{C}-\mathrm{H}^{\cdots} \cdots \mathrm{W}$ interaction. Color code of atoms (online version): W (orange), C (black), O (red), $\mathrm{H}$ (white), S (yellow). 
shows where the first two electrons will be removed during oxidation of the one $\mathrm{W}$-centre to form a mixed valent carbene W(II)-W(0) complex. Removal of two more electrons (from the HOMO-1 of the original neutral complex) leads to the second oxidation, at a higher potential, with formation of the W(II)-W(II) complex of charge +4 . The octahedral arrangement of the ligands round the two metal centers in the electrochemically unstable oxidized W(II)-W(II) complex is distorted, see Figure 9. For each $\mathrm{W}$ atom a short interaction is observed to a hydrocarbon of the ethoxy group. The $\mathrm{d}\left(\mathrm{H}^{\cdots \cdots} \mathrm{W}\right)$ of $c a .2 .2 \AA$ and the $\mathrm{W}-\mathrm{H}-\mathrm{C}$ angle of $c a .120^{\circ}$ fall well in the range of $1.8-2.3 \AA$ and 90 - $140^{\circ}$, typical for a C-H'”Metal agostic interaction [43].

During reduction of the biscarbene complexes (7) - (9), an electron is added to the LUMO of the complex. The character of the LUMO shows where reduction takes place. The DFT calculated LUMO (closed shell, containing an $\alpha$ and a $\beta$ electron) and LUMO +1 are both distributed over the two carbene carbons and the aryl group, and the LUMO+2 on the CO-groups. The first two reduction processes observed for the biscarbene complexes $(\mathbf{7})-(\mathbf{9})$, at potentials $<-0.5 \mathrm{~V}$, are thus associated with the carbene centre's. The first reduction process has an influence on the second one, due to electron delocalisation via the bridging unit. The first reduction process of the biscarbene complexes $(\mathbf{7})-(9)$, occurs at a less negative potential than the first reduction process of the related monocarbene complexes (1) - (3) (see the dotted lines in Figure 4).

The biscarbene complexes (10) and (11), containing two thienyl bridging units, exhibit one large oxidation peak, consistent with the simultaneous oxidation of the two $\mathrm{W}$ metals. The larger more flexible bridging unit makes it possible for the two W-metal centers to be in simultaneous contact with the electrode to be oxidized simultaneously. The oxidation potential of (10) and (11) is very similar to the oxidation potential of the related monocarbene complex (1), see the blue dotted lines in Figure 10. The oxidation potentials of (4) (two thienyl rings) and (12) (three thienyl rings) are also within a few millivolt of the oxidation potential of (1) (one thienyl ring), illustrating the fact that the W-based oxidation is largely influenced by the first aryl ring attached to the carbene carbon.

The first reduction of biscarbene complexes (7), (10) and (11), however, occurs much easier, at a ca. $0.5 \mathrm{~V}$ less negative potential than the first reduction of the related monocarbene complex $\mathbf{1}$, see Figure 10. From a quantum chemistry point of view, the LUMO energy of (7), (10) and (11) is much lower than that of complex (1), making the reduction of (7), (10) and (11) easier than that of (1). The added electron during the reduction of (10) and (11) can be distributed over two thienyl units, making the reduced complex relative more stable to such an extent that a re-oxidation peak of the reduction process is observed, with $\Delta E \approx 0.115 \mathrm{~V}$ in $\mathrm{CH}_{3} \mathrm{CN}$, making the reduction process 

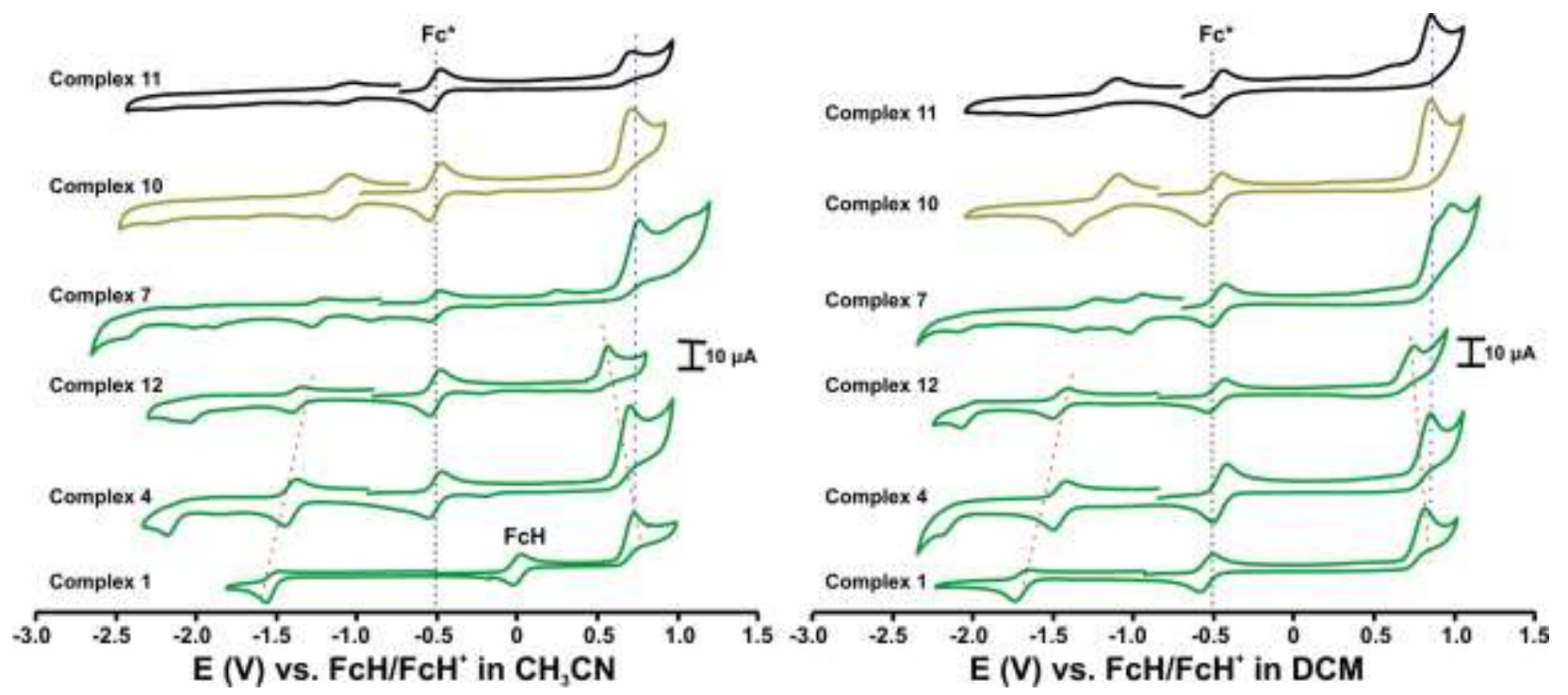

Figure 10. Comparative cyclic voltammograms of $c a .0 .0005 \mathrm{~mol} \mathrm{dm}{ }^{-3}$ solutions of the thienyl-containing complexes.

quasi reversible. A similar phenomenon is observed when the reduction of (1) (one thienyl ring) to (4) (two thienyl rings) to (12) (three thienyl rings) is compared; the re-oxidation peak of the reduction process is more prominent and $\Delta E$ in $\mathrm{CH}_{3} \mathrm{CN}$ decreases from $0.086 \mathrm{~V}$ to $0.074 \mathrm{~V}$ to 0.064 $\mathrm{V}$, since the added electron is distributed over more thienyl units. The delocalization of the added electron can be visualized by the spin density plot of the reduced complexes, see Figure 11.
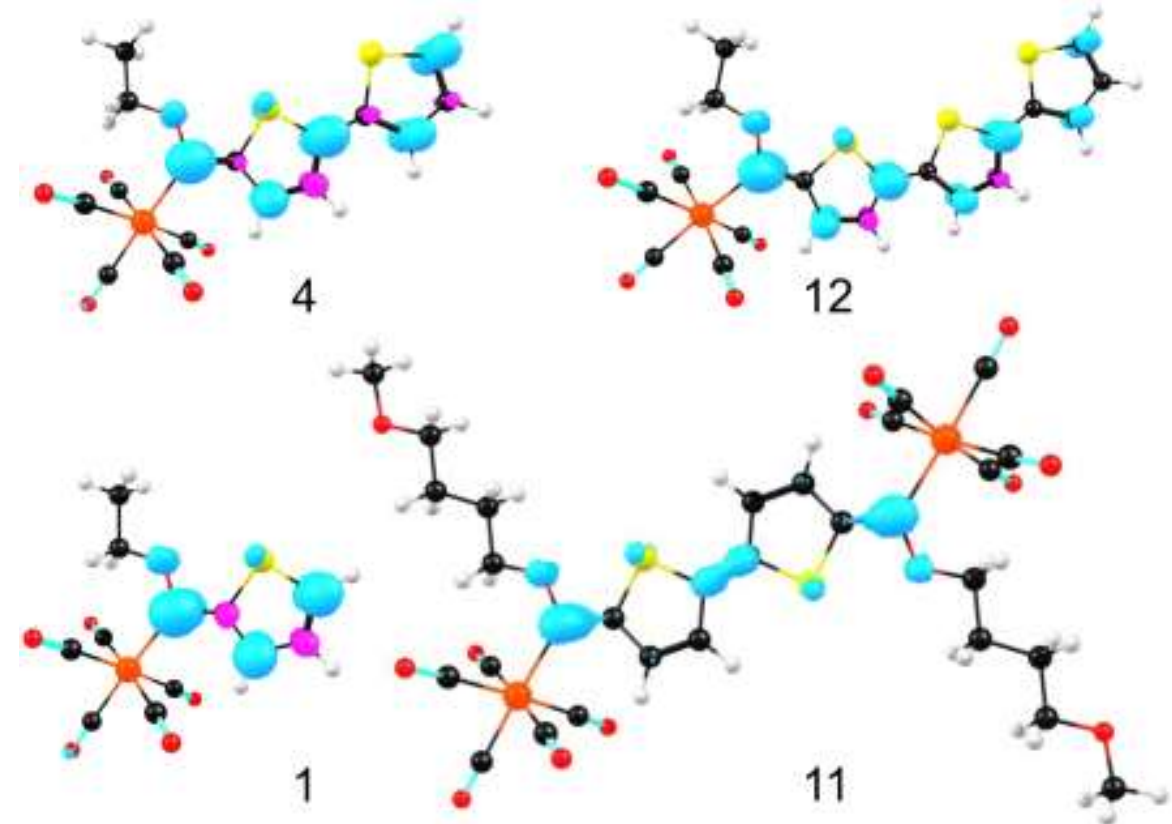

Figure 11. DFT calculated Mulliken spin density plots of the optimized reduced radical anion $(q=-1, S=1 / 2)$ of complexes (1), (4), (11) and (12). The spin density plots use a contour of $6 \mathrm{e} / \mathrm{nm}^{3}$. Color code of atoms (online version): W (orange), C (black), O (red), H (white), S (yellow).

For the dimeric complex (7) with a direct thienyl ring as linker, two reduction peaks, associated with the reduction of the two carbene carbons, are observed, while dimeric complexes (11) and (12) 
with two thienyl rings as linker, produce only one reduction peak; proposed to be the simultaneous reduction of the two carbene carbons. A similar observation was made for the oxidation of the W centers, where (7) showed two (near overlapping) oxidations and (11) and (12) only one large simultaneous oxidation of the $\mathrm{W}$ centers (discussed above).

\section{Relationships involving 36 structurally modified Fischer carbene complexes of tungsten}

Oxidation involves the removal of an electron from the HOMO and the reduction process the addition of an electron to the LUMO. The potentials of the first oxidation and first reduction of a complex can thus be correlated to the energies of its highest occupied molecular orbital (HOMO) and lowest unoccupied molecular orbital (LUMO), respectively. These two relationships for a series of 36 Fischer carbene complexes of tungsten over a large potential range $(0.91 \mathrm{~V}$ for the oxidation and 1.6 V for the reduction), are presented in Figure 12 (see supporting information
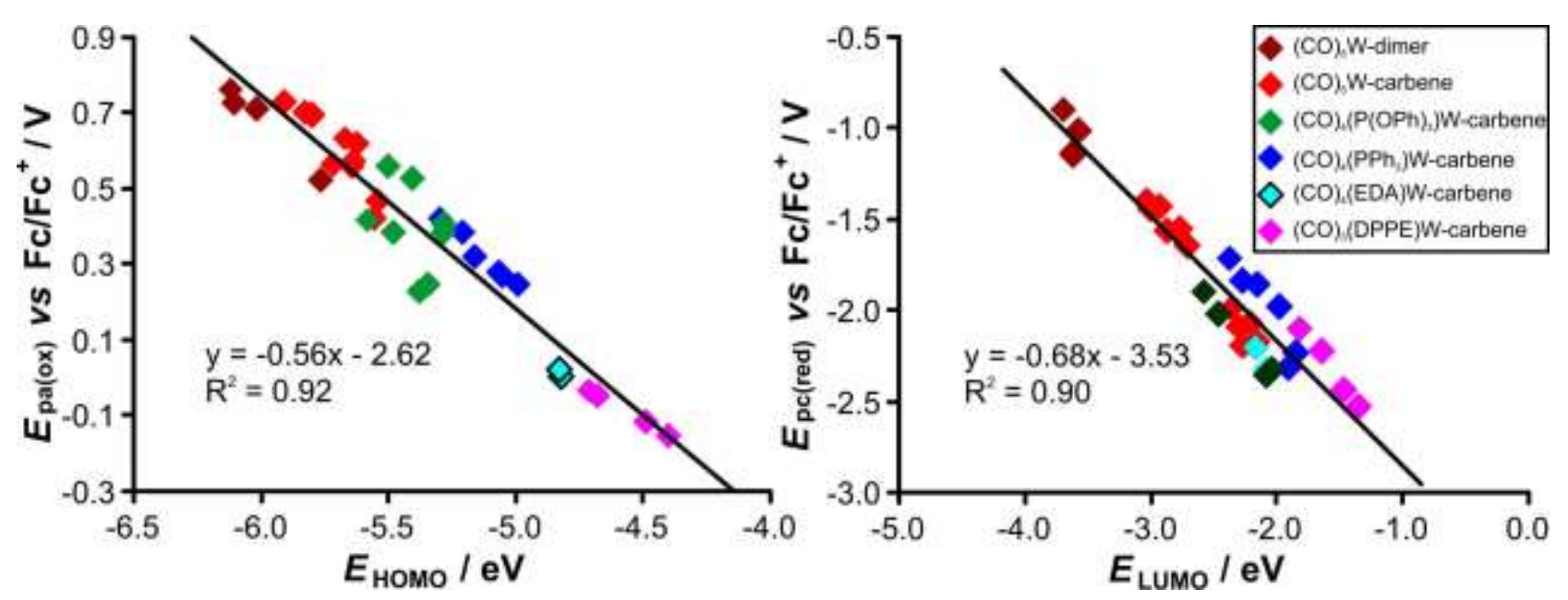

Figure 12. Linear relationship between the DFT calculated energies and experimental potentials of complexes (1) (36) (see the supporting information Scheme $S 1$ for the structures of (13) - (36)) of $E_{\mathrm{HOMO}}$ and the oxidation potential $E_{\mathrm{pa}}$ of the first oxidation process (left) and $E_{\mathrm{LUMO}}$ and the reduction potential $E_{\mathrm{pc}}$ of the first reduction process (right). Data are in Table 2 and from reference [5] and [9]. Experimental potentials are measured in $0.1 \mathrm{~mol} \mathrm{dm}^{-3}$ $\left[{ }^{\mathrm{n}}\left(\mathrm{Bu}_{4}\right) \mathrm{N}\right]\left[\mathrm{PF}_{6}\right] / \mathrm{CH}_{3} \mathrm{CN}$ and reported relative to the $\mathrm{FcH} / \mathrm{FcH}^{+}$couple.

Scheme S1 for the structures of complexes $(\mathbf{1 3})-(\mathbf{3 6}))$. The relationships include a variety of modified Fischer carbene complexes of tungsten containing

(a) different heteroarene substituents on the carbene ligand ( $\mathrm{Fu}$, Th or NMe-pyrrole)

(b) different heteroatom substituents ( $\mathrm{O}$ vs $\mathrm{N}$ [5])

(c) different ligands directly attached to the metal $\left(\mathrm{PPh}_{3}, \mathrm{P}(\mathrm{OPh})_{3}\right.$, dppe $(1,2-$

bis(diphenylphosphino)ethane), or the chelated product of ethylene diamine [9])

(d) different dimeric heteroarene substituents and 
Table 1. Cyclic voltammetry data of $c a .0 .0005 \mathrm{~mol} \mathrm{dm}^{-3}$ solutions of $(\mathbf{1})-(\mathbf{1 2})$ in DCM or $\mathrm{CH}_{3} \mathrm{CN}$ containing $\left.0.1 \mathrm{~mol} \mathrm{dm}^{-3}\left[\mathrm{~N}^{n}{ }^{n} \mathrm{Bu}\right)_{4}\right]\left[\mathrm{PF}_{6}\right]$ as supporting electrolyte at a scan rate of $0.100 \mathrm{~V} \mathrm{~s}^{-1}$ and $20{ }^{\circ} \mathrm{C}$. Potentials are reported in $\mathrm{V}$ relative to the $\mathrm{FcH} / \mathrm{FcH}^{+}$couple.

\begin{tabular}{|c|c|c|c|c|c|c|c|c|c|c|c|c|c|c|c|}
\hline & \multicolumn{6}{|c|}{ Experimental in $\mathrm{CH}_{3} \mathrm{CN}$} & \multicolumn{6}{|c|}{ Experimental in DCM } & \multicolumn{3}{|c|}{ DFT calculations } \\
\hline & \multirow{2}{*}{$\begin{array}{l}\text { Oxidation } \\
\mathrm{E}_{\mathrm{pa}(\mathrm{ox})} \\
/ \mathrm{V}\end{array}$} & \multicolumn{4}{|c|}{ reduction 1} & \multirow[b]{2}{*}{$\begin{array}{l}\mathrm{E}_{\mathrm{pa}(\text { ox } 1)^{-}} \\
\mathrm{E}_{\mathrm{pc}(\mathrm{red})} \\
/ \mathrm{V}\end{array}$} & \multirow{2}{*}{$\begin{array}{l}\text { Oxidation } \\
\mathrm{E}_{\mathrm{pa}(\mathrm{ox})} \\
/ \mathrm{V}\end{array}$} & \multicolumn{4}{|c|}{ reduction 1} & \multirow[b]{2}{*}{$\begin{array}{l}\mathrm{E}_{\mathrm{pa}(\mathrm{ox} 1)^{-}} \\
\mathrm{E}_{\mathrm{pc}(\mathrm{red})} \\
/ \mathrm{V}\end{array}$} & \multirow[b]{2}{*}{$\begin{array}{l}\mathrm{E}_{\text {Номо }} \\
/ \mathrm{eV}\end{array}$} & \multirow[b]{2}{*}{$\begin{array}{l}\mathrm{E}_{\mathrm{LUMO}} \\
/ \mathrm{eV}\end{array}$} & \multirow[b]{2}{*}{$\begin{array}{l}\mathrm{E}_{\mathrm{HOMO}}- \\
\mathrm{E}_{\mathrm{LUMO}} \\
/ \mathrm{eV}\end{array}$} \\
\hline & & $\begin{array}{l}\mathrm{E}_{\mathrm{pa}(\mathrm{red})} \\
/ \mathrm{V}\end{array}$ & $\begin{array}{l}\mathrm{E}_{\mathrm{pc}(\mathrm{red})} \\
/ \mathrm{V}\end{array}$ & $\begin{array}{l}\Delta \mathrm{E} \\
/ \mathrm{V}\end{array}$ & $\begin{array}{l}\mathrm{E}^{0} \\
/ \mathrm{V}\end{array}$ & & & $\begin{array}{l}\mathrm{E}_{\mathrm{pa}(\mathrm{red})} \\
/ \mathrm{V}\end{array}$ & $\begin{array}{l}\mathrm{E}_{\mathrm{pc}(\mathrm{red})} \\
/ \mathrm{V}\end{array}$ & $\begin{array}{l}\Delta \mathrm{E} \\
/ \mathrm{V}\end{array}$ & $\begin{array}{l}\mathrm{E}^{0^{\prime}} \\
/ \mathrm{V}\end{array}$ & & & & \\
\hline 1 & 0.728 & -1.478 & -1.564 & 0.086 & -1.521 & 2.292 & 0.812 & -1.654 & -1.742 & 0.088 & \begin{tabular}{|l|}
-1.698 \\
\end{tabular} & 2.554 & -5.907 & -2.873 & -3.034 \\
\hline 2 & 0.697 & -1.559 & -1.645 & 0.086 & -1.602 & 2.342 & 0.800 & -1.768 & -1.862 & 0.094 & -1.815 & 2.662 & -5.798 & -2.725 & -3.072 \\
\hline 3 & 0.632 & -1.932 & -1.994 & 0.062 & -1.963 & 2.626 & 0.683 & -2.047 & -2.153 & 0.106 & -2.100 & 2.836 & -5.67 & -2.37 & -3.304 \\
\hline 4 & 0.702 & -1.374 & -1.448 & 0.074 & -1.411 & 2.150 & 0.845 & -1.423 & -1.505 & 0.082 & -1.464 & 2.350 & -5.825 & -3.009 & -2.816 \\
\hline 5 & 0.695 & -1.363 & -1.435 & 0.072 & -1.399 & 2.130 & 0.789 & -1.505 & -1.617 & 0.112 & -1.561 & 2.406 & -5.800 & -2.940 & -2.860 \\
\hline 6 & 0.572 & -1.486 & -1.552 & 0.066 & -1.519 & 2.124 & 0.661 & -1.607 & -1.713 & 0.106 & -1.660 & 2.374 & -5.640 & -2.779 & -2.860 \\
\hline 7 & $0.761 ; 1.011$ & -0.843 & -0.913 & 0.070 & -0.878 & 1.674 & $0.891 ; 0.979$ & -0.945 & -1.023 & 0.078 & -0.984 & 1.914 & -6.123 & -3.678 & -2.444 \\
\hline 8 & $0.712 ; 0.738$ & -0.952 & -1.020 & 0.068 & -0.986 & 1.732 & $0.885 ; 0.885$ & -1.059 & -1.147 & 0.088 & -1.103 & 2.032 & -6.105 & -3.576 & -2.529 \\
\hline 9 & $0.523 ; 0.710$ & - & - & - & - & - & $0.574 ; 0.760$ & -1.338 & -1.422 & 0.084 & -1.380 & 1.996 & -5.764 & -3.243 & -2.521 \\
\hline 10 & 0.713 & -1.037 & -1.153 & 0.116 & -1.095 & 1.866 & 0.845 & -1.095 & -1.395 & 0.300 & -1.245 & 2.240 & -6.018 & -3.625 & -2.393 \\
\hline 11 & 0.713 & -1.027 & -1.141 & 0.114 & -1.084 & 1.854 & 0.851 & -1.103 & -1.571 & 0.468 & -1.337 & 2.422 & -6.016 & -3.627 & -2.389 \\
\hline 12 & 0.563 & -1.341 & -1.405 & 0.064 & -1.373 & 1.968 & 0.745 & -1.415 & -1.511 & 0.096 & -1.463 & 2.256 & -5.717 & -3.035 & -2.681 \\
\hline
\end{tabular}


(e) another pentacarbonyl carbene unit (biscarbenes) on W(0) pentacarbonyl Fischer carbene complexes.

We further observe that the tungsten pentacarbonyl biscarbene complexes (7), (8), (10) and (11) presented in this study, where the two units are connected with a furyl or one or more thienyl linkers, exhibit the highest first reduction potentials measured for tungsten Fischer carbene complexes to date. Complex (7) exhibit the highest first oxidation potential measured for tungsten Fischer carbene complexes to date.

\section{Conclusion}

An electrochemical study of the first oxidation and first reduction of (1) - (12) revealed that the ease of oxidation and reduction is related to the influence of the heteroarene ligand attached to it, irrespective whether the carbene complex contains a mono- or a dimeric heteroarene ligand or if it is a biscarbene complex. The order obtained within a series of related carbenes, is, higher oxidation and higher reduction potential $\mathrm{Th}>\mathrm{Fu}>(\mathrm{NMe})$ py.

\section{Acknowledgements}

This work has received support from the Norwegian Supercomputing Program (NOTUR) through a grant of computer time (Grant No. NN4654K) (JC), the South African National Research Foundation (JC), the Central Research Fund of the University of the Free State, Bloemfontein (JC) and the University of Pretoria (ML and PHvR). The authors thank Prof S Lotz (University of Pretoria) for some of the samples.

\section{References}

[1] E.O. Fischer, A. Maasböl, Zur Frage eines Wolfram-Carbonyl-Carben-Komplexes, Angewandte Chemie, 76 (1964) 645-645. DOI:10.1002/ange.19640761405

[2] P.J. Krusic, U. Klabunde, C.P. Casey, T.F. Block, Journal of the American Chemical Society 98 (1976) 2015-2018.

[3] W.I. Dzik, X.P. Zhang, B. de Bruin, Redox Noninnocence of Carbene Ligands: Carbene Radicals in (Catalytic) C-C Bond Formation, Inorganic Chemistry 50 (2011) 9896-9903.

[4] M.A. Sierra, M. Gómez-Gallego, R. Martínez-Álvarez, Fischer Carbene Complexes: Beautiful Playgrounds To Study Single Electron Transfer (SET) Reactions, Chemistry European Journal 13 (2007) 736-744.

[5] M. Landman, R. Pretorius, B.E. Buitendach, P.H. van Rooyen, J. Conradie, Synthesis, structure and electrochemistry of Fischer alkoxy- and aminocarbene complexes of tungsten: The use of 
DFT to predict and understand oxidation and reduction potentials, Organometallics 32 (2013) 5491-5503.

[6] C. Baldoli, P. Cerea, L. Falciola, C. Giannini, E. Licandro, S. Maiorana, P. Mussini, D. Perdicchia, The electrochemical activity of heteroatom-stabilized Fischer-type carbene complexes, Journal of Organometallic Chemistry 690 (2005) 5777-5787.

[7] I. Hoskovcová, J. Roháčová, D. Dvořák, T. Tobrman, S. Záliš, R. Zvěřinová, J. Ludvík, Synthesis and electrochemical study of iron, chromium and tungsten aminocarbenes: Role of ligand structure and central metal nature, Electrochimica Acta 55 (2010) 8341-8351.

[8] (a) B. van der Westhuizen, J.M. Speck, M. Korb, J. Friedrich, D.I. Bezuidenhout, H. Lang, Metal-Metal Interaction in Fischer Carbene Complexes: A Study of Ferrocenyl and Biferrocenyl Tungsten Alkylidene Complexes, Inorganic Chemistry 52 (2013) 14253-14263;

(b) D.I. Bezuidenhout, I. Fernández, B. van der Westhuizen, P.J. Swarts, J.C. Swarts, Electrochemical and Computational Study of Tungsten(0) Ferrocene Complexes: Observation of the Mono-Oxidized Tungsten(0) Ferrocenium Species and Intramolecular Electronic Interactions, Organometallics 32 (2013) 7334-7344.

[9] M. Landman, R. Pretorius, R. Fraser, B.E. Buitendach, M.M. Conradie, P.H. van Rooyen, J. Conradie, Electrochemical behaviour and structure of novel phosphine- and phosphite substituted tungsten(0) Fischer carbene complexes, Electrochimica Acta 130 (2014) 104-118.

[10] D.F. Shriver, M.A. Drezdon, The manipulation of air sensitive compounds, 2nd ed., John Wiley and Sons, New York, 1986.

[11] G.H. Spies, R.J. Angelici, Model Studies of Thiophene Hydrodesulfurization Using ( $\eta$ Thiophene) $\mathrm{Ru}\left(\eta-\mathrm{C}_{5} \mathrm{H}_{5}\right)^{+}$: Reactions Leading to C-S Bond Cleavage, Organometallics 6 (1987) 1897-1903.

[12] H. Meerwein, Triethyloxonium Fluoborate, Organic Syntheses 46 (1966) 113-115. DOI:10.15227/orgsyn.046

[13] S. Lotz, C. Crause, A.J. Olivier, D.C. Liles, H. Gorls, M. Landman, D.I. Bezuidenhout, Synthesis and reactivity of metal carbene complexes with heterobiaryl spacer substituents, Dalton Transactions (2009) 697-710.

[14] S. Aoki, T. Fujimura, E. Nakamura, A protective strategy in carbene complex chemistry. Synthesis of functionalized Fischer carbene complexes via dianion formation, Journal of the American Chemical Society 114 (1992) 2985-2990.

[15] C. Crause, H. Gorls, S. Lotz, Binuclear biscarbene complexes of furan, Dalton Transactions (2005) 1649-1657.

[16] A.J. Olivier, MSc dissertation, Novel carbene complexes with pyrrole ligands, University of Pretoria, 2001.

[17] M. Landman, J. Ramontja, M. van Staden, D.I. Bezuidenhout, P.H. van Rooyen, D.C. Liles, S. Lotz, Properties of homo- and heteronuclear mixed biscarbene complexes with conjugated bithiophene units, Inorganica Chimica Acta 363 (2010) 705-717.

[18] S. Lotz, N.A. van Jaarsveld, D.C. Liles, C. Crause, H. Görls, Y.M. Terblans, Fischer Dinuclear and Mononuclear Biscarbene Complexes of Thiophene and Thiophene Derivatives, Organometallics 31 (2012) 5371-5383.

[19] S. Lotz, M. Landman, H. Gorls, C. Crause, H. Nienaber, A. Olivier, Di-tungsten Bis-carbene Complexes Linked by Condensed Heteroaromatic Spacers, Zeitschrift für Naturforschung 62b (2007) 419-426.

[20] M.M. Moeng, MSc dissertation, Terthienyl carbene complexes, University of Pretoria, Pretoria, 2001.

[21] B.S. Furniss, A.J. Hannaford, P.W.G. Smith, A.R. Tatchell, in: Vogel's Textbook of Practical Organic Chemistry, 5th ed., John Wiley \& Sons, New York, 1994, pp. 409.

[22] APEX2 (including SAINT and SADABS), Bruker AXS Inc., Madison, Wisconsin, USA, 2013.

[23] G.M. Sheldrick, A short history of SHELX, Acta Crystallographica A64 (2008) 112-122.

[24] L.J. Farrugia, ORTEP-3 for Windows - a version of ORTEP-III with a Graphical User Interface (GUI), Journal of Applied Crystallography 30 (1997) 565-565. 
[25] D.T. Sawyer, J.L. Roberts Jr., Experimental Electrochemistry for Chemists, Wiley, New York, 1974, p.54.

[26] G. Gritzner, J. Kuta, Recommendations on reporting electrode potentials in nonaqueous solvents, Pure and Applied Chemistry 56 (1984) 461-466.

[27] A.J.L. Pombeiro, Electron-donor/acceptor properties of carbynes, carbenes, vinylidenes, allenylidenes and alkynyls as measured by electrochemical ligand parameters, Journal of Organometallic Chemistry 690 (2005) 6021-6040.

[28] A.D. Becke, Density-functional exchange-energy approximation with correct asymptotic behavior, Physical Review A 38 (1988) 3098-3100.

[29] C.T. Lee, W.T. Yang, R.G. Parr, Development of the Colle-Salvetti correlation-energy formula into a functional of the electron-density, Physical Review B 37 (1988) 785-789.

[30] M.J. Frisch, G.W. Trucks, H.B. Schlegel, G.E. Scuseria, M.A. Robb, J.R. Cheeseman, G. Scalmani, V. Barone, B. Mennucci, G.A. Petersson, H. Nakatsuji, M. Caricato, X. Li, H.P. Hratchian, A.F. Izmaylov, J. Bloino, G. Zheng, J.L. Sonnenberg, M. Hada, M. Ehara, K. Toyota, R. Fukuda, J. Hasegawa, M. Ishida, T. Nakajima, Y. Honda, O. Kitao, H. Nakai, T. Vreven, J.A. Montgomery (Jr), J.E. Peralta, F. Ogliaro, M. Bearpark, J.J. Heyd, E. Brothers, K.N. Kudin, V.N. Staroverov, T. Keith, R. Kobayashi, J. Normand, K. Raghavachari, A. Rendell, J.C. Burant, S.S. Iyengar, J. Tomasi, M. Cossi, N. Rega, J.M. Millam, M. Klene, J.E. Knox, J.B. Cross, V. Bakken, C. Adamo, J. Jaramillo, R. Gomperts, R.E. Stratmann, O. Yazyev, A.J. Austin, R. Cammi, C. Pomelli, J.W. Ochterski, R.L. Martin, K. Morokuma, V.G. Zakrzewski, G.A. Voth, P. Salvador, J.J. Dannenberg, S. Dapprich, A.D. Daniels, O. Farkas, J.B. Foresman, J.V. Ortiz, J. Cioslowski, D.J. Fox, Gaussian 09, Revision C.01, Gaussian Inc., Wallingford CT, 2010.

[31] F. Weigend, R. Ahlrichs, Balanced basis sets of split valence, triple zeta valence and quadruple zeta valence quality for $\mathrm{H}$ to $\mathrm{Rn}$ : Design and assessment of accuracy, Physical Chemistry Chemical Physics 7 (2005) 3297-3305.

[32] M.J. Cook, I. Chambrier, G.F. White, E. Fourie, J.C. Swarts, Electrochemical and EPR studies of two substituted bis-cadmium tris-phthalocyanine complexes: elucidation of unexpectedly different free-radical character, Dalton Transactions 7 (2009) 1136-1144.

[33] E. Fourie, J.C. Swarts, I. Chambrier, M.J. Cook, Electrochemical and spectroscopic detection of self-association of octa-alkyl phthalocyaninato cadmium compounds into dimeric species, Dalton Transactions 7 (2009) 1145-1154.

[34] G.A. Mabbott, An introduction to cyclic voltammetry, Journal of Chemical Education 60 (1983) 697-702.

[35] P.T. Kissinger, W.R. Heineman, Cyclic voltammetry, Journal of Chemical Education 60 (1983) 702-706.

[36] J.J. van Benschoten, J.Y. Lewis, W.R. Heineman, D.A. Roston, P.T. Kissinger, Cyclic voltammetry experiment, Journal of Chemical Education 60 (1983) 772-776.

[37] R.E. Kagarise, Relation between the Electronegativities of Adjacent Substituents and the

Stretching Frequency of the Carbonyl Group, Journal of the American Chemical Society 77 (1995)

1377-1379.

[38] J.A. Connor, E.M. Jones, Stabilisation of nucleophilic carbenes co-ordinated to transition metals, Journal of the Chemical Society, A (1971) 1974-1979.

[39] M.K. Lloyd, J.A. McCleverty, D.G. Orchard, J.A. Connor, M.B. Hall, I.H. Hillier, E.M. Jones, G.K. McEwen, Electrochemical Oxidation of Organometallic Complexes. Carbene and Lewis Base Complexes of Chromium, Molybdenum, and Tungsten Carbonyl, Dalton Transactions (1973) 1743-1747.

[40] A. Kuhn, J. Conradie, Electrochemical and Density Functional Theory Study of bis(cyclopentadienyl) mono( $\beta$-diketonato) titanium(IV) cationic complexes, Electrochimica Acta 56 (2010), 257-264.

[41] R. Metelková, T. Tobrman, H. Kvapilová, I. Hoskovcová, J. Ludvík, Synthesis, characterization and electrochemical investigation of hetaryl chromium $(0)$ aminocarbene complexes, Journal Electrochimica Acta 82 (2012) 470-477. 
[42] (a) C. Creutz, H.J. Taube, Direct approach to measuring the Franck-Condon barrier to electron transfer between metal ions, Journal of the American Chemical Society 91 (1969) 3988-3989;

(b) N. van Order, W.E. Geiger, T.E. Bitterwolf, A.L. Reingold, Mixed-Valent Cations of Dinuclear Chromium Aryl Complexes: Electrochemical, Spectroscopic, and Structural Consideration, Journal of the American Chemical Society 109 (1987) 5680-5690;

(c) D.T. Pierce, W.E. Geiger, Mixed-Valent Interactions in Rigid Dinuclear Systems Electrochemical and Spectroscopic Studies Of Cr-I-Cr-O Ions with Controlled Torsion of the Biphenyl Bridge, Inorganic Chemistry 33 (1994) 373-381;

(d) W.E. Geiger, N. van Order, D.T. Pierce, T.E. Bitterwolf, A.L. Reingold, N.D. Chasteen, Class II mixed-valent complexes from oxidation of doubly linked (arene)chromium compounds, Organometallics 10 (1991) 2403-2411;

(e) K.C. Kemp, E. Fourie, J. Conradie, J.C. Swarts, Ruthenocene-Containing $\beta$-Diketones: Synthesis, $\mathrm{pKa}^{\prime}$ Values, Keto-Enol Isomerization Kinetics, and Electrochemical Aspects, Organometallics 27 (2008) 353-362;

(f) J. Conradie, J.C. Swarts, Relationship Between Electrochemical Potentials and Substitution Reaction Rates of Ferrocene-Containing $\beta$-Diketonato Rhodium(I) Complexes: Cytotoxicity of [Rh(FcCOCHCOPh)(cod)], Dalton Transactions 40 (2011) 5844-5851.

DOI: $10.1039 / \mathrm{C} 1 \mathrm{DT} 00013 \mathrm{~F}$

[43] M. Brookhart, M.L.H. Green, G. Parkin, Agostic interactions in transition metal compounds, Proceedings of the National Academy of Sciences USA 104 (2007) 6908-6914. 